\title{
The Impact of Financial Ratios on the Dividend Payout Ratio in Coal Mining Companies
}

\author{
Aldo Sebastian $^{1 *}$, Rahmat Siauwijaya ${ }^{2}$ \\ Accounting Department, Faculty of Economics and Communication \\ Bina Nusantara University \\ Jakarta 11480, Indonesia \\ aldo.sebastian@binus.ac.id; rahmat.siauwijaya@binus.ac.id \\ *Correspondence: aldo.sebastian@binus.ac.id
}

\begin{abstract}
The purpose of this study is to determine the impacts of current ratio, debt to equity ratio, return on asset, total asset turnover ratio, and working capital turnover ratio on the dividend payout ratio in coal mining companies listed in Indonesia Stock Exchange 2016-2018. The sample used in this study was determined based on a purposive sampling method. The type of data used in this study is secondary data and the technique used to analyze the data in this study is panel data regression analysis.

The results show that the debt to equity ratio has a negative and significant effect on the dividend payout ratio. While, current ratio, return on asset, total asset turnover ratio, and working capital turnover ratio have no significant effect on the dividend payout ratio.
\end{abstract}

Keywords: Dividend payout ratio; Current ratio; Debt to equity ratio; Return on asset; Total asset turnover ratio; Working capital turnover ratio.

\section{INTRODUCTION}

\section{Research Background}

Coal is one of the essential sources of energy in the world. The reason is that, worldwide, nearly $40 \%$ of all powerplants used it as fuel. Indonesia itself is the fifth-largest coal producer after China, India, the USA, and Australia.

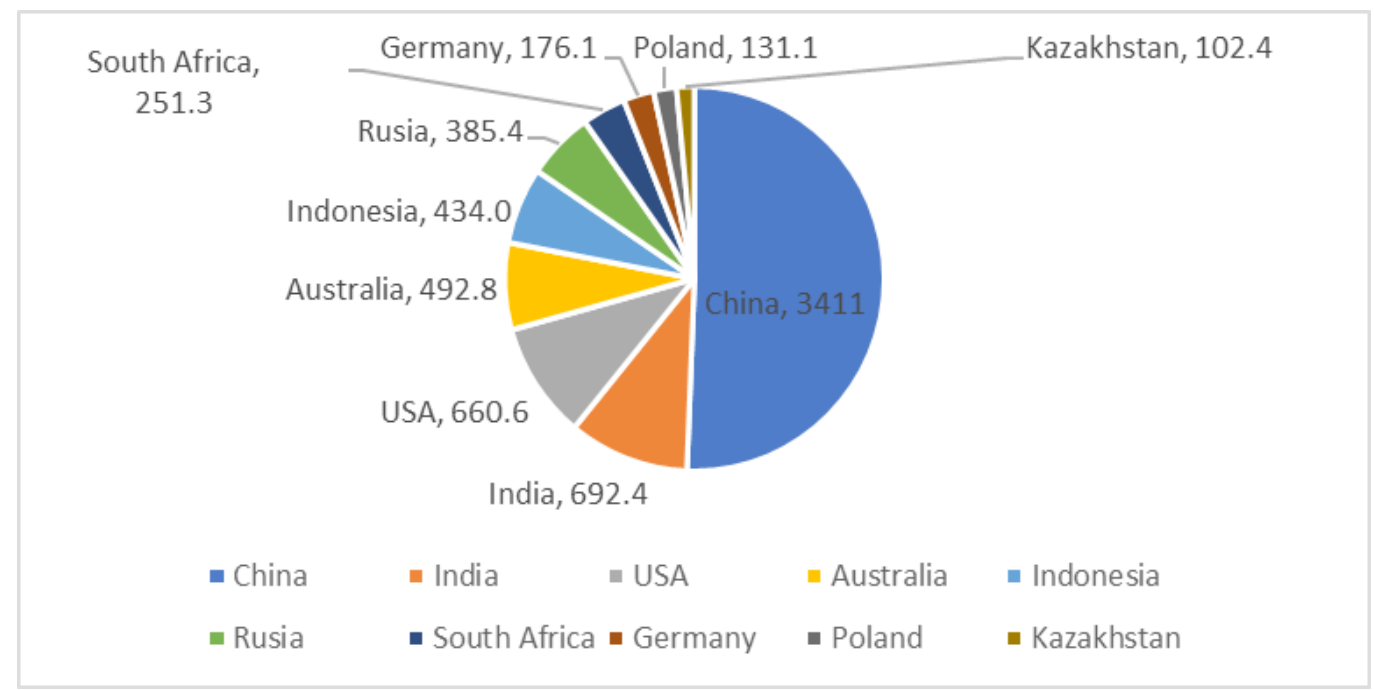

Figure 1. Coal-Producing Countries (million tons per year).

Source: CNBC Indonesia (2019) 
From 2014 to 2018, Indonesia's coal production has increased by 70 million tons or $15.28 \%$ from 458 million tons to 528 million tons. Coal demand from abroad has also increased by 70 to 80 percent of total production.

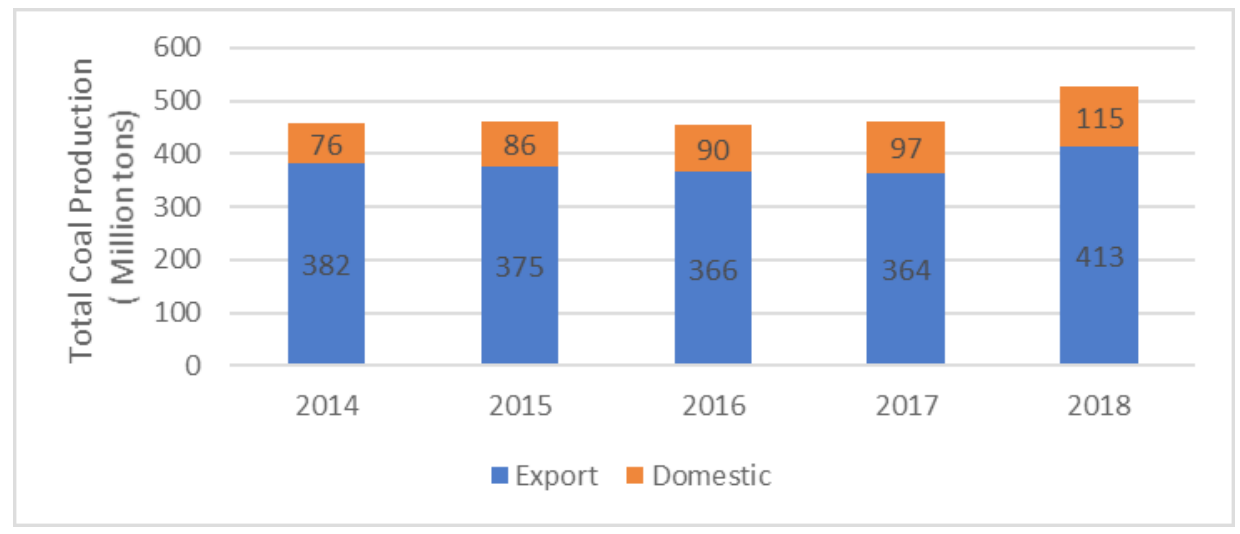

Figure 2. Indonesian Coal Production (million tons per year) Source: Indonesian Central Bureau of Statistics

Coal mining is one of the businesses that earn foreign currencies for Indonesia. Based on figure 2, Indonesian coal exports increased by 31 million tons or $8.12 \%$ from 382 million tons to 413 million tons. Indonesia's five major coal export destination countries are India, China, Japan, South Korea, and Taiwan.

Based on data in Figures 1 and 2, it can be said that coal mining is a profitable business sector in Indonesia. However, according to the data obtained, only eight coal companies out of twenty-two coal companies paid dividends for three consecutive years from 2016 to 2018 , or only $36.36 \%$ of coal companies paid dividend in 2016 to 2018 consecutively. Those eight companies experienced an increase in assets, liabilities, sales/income, and net income instead. The fact mentioned earlier is what makes the topic a fascinating phenomenon to research.

The research topic about the impact of financial ratios on the dividend payout ratio in coal mining sector companies is minimal. Similar research has been conducted in the manufacturing, automotive, basic-industry, and chemical companies. This research was conducted comprehensively by combining several variables that were researched separately. This research also adds a new variable: working capital turnover ratio, which might influence the dividend payout ratio.

\section{Problem Formulation}

Based on the description of the phenomena above, this research formulates problems that will be answered in this research, namely:

- Does the current ratio, debt to equity ratio, return on asset, total asset turnover ratio, and working capital turnover ratio partially affect the dividend payout ratio of coal mining companies?

\section{Research Objectives}

Regarding the problems that have been formulated, this research aims to analyze the impact of current ratio, debt to equity ratio, return on assets, total asset turnover ratio, and working capital turnover ratio on the dividend payout ratio in the coal mining sector companies.

\section{Literature Review}

According to the Indonesian Accounting Association (2015), the definition of financial statements in Standar Akuntansi Keuangan (SAK) No. 1 described that financial statements are part of the financial reporting process. Financial statements are a structured presentation of the financial position and financial performance of an entity. The complete set of financial statements usually includes the balance sheet, income statement, statement of cash flows, and stockholders' equity statement.

Financial statements are the most reliable information source and one factor that can form an opinion on a company's financial position. (Osadchy et.al., 2018).

Analysis of financial statements is a preliminary step towards short-medium-and long-term planning of the company's activities. The system of financial reporting indicators contains four criteria: relevance, reliability, 
comparability, and clarity (Abib et.al., 2015 in the Osadchy et.al., 2018).

Financial ratios are mainly used for their simplicity and additional information value in the practice of financial analysis. These ratios make it possible to analyze the development of a firm's financial situation (trend analysis), cross-sectional analysis, and comparative analysis. Financial ratios can be categorized into indicators. Financial ratios are the most popular and most widely used financial analysis methods because they can be used as input data of more mathematically complex models (Myšková \& Hájek, 2017).

The company's goal is to maximize shareholder value. The dividend payout ratio is defined as the percentage of net income to be paid in dividends, or the ratio between the profit paid in the form of dividends and the total profit available to shareholders. Dividend policy must balance between current dividends and future growth that maximizes the share price (Brigham \& Houston, 2019).

\section{METHODS}

\section{Sample Collection Method}

This study's population are coal mining companies listed on the Indonesia Stock Exchange for the period 2016-2018, with a total population of 22 companies. Sampling using purposive sampling technique, where the sample selected must be following predetermined criteria. The criteria used in determining the sample are as follows:

- Coal mining sector companies did not leave the Indonesian Stock Exchange (IDX) during the research period, namely 2016-2018.

- Issuing audited annual financial statements as of December 31 $1^{\text {st }}, 2016$, to December $31^{\text {st }}, 2018$.

- The company makes consecutive dividend payments during the research period.

Table 1. Coal Mining Company Sample Selection Table

\begin{tabular}{clc}
\hline No. & \multicolumn{1}{c}{ Criteria } & Total \\
\hline 1. & Coal mining companies listed on the Indonesian Stock Exchange from 2016 through 2018 & 22 \\
\hline 2. & Companies delisted from the Indonesian Stock Exchange. & 4 \\
\hline 3. $\quad$ Companies that do not publish audited financial statements & 2 \\
\hline 4. $\quad$ Companies that do not pay dividends & 8 \\
\hline $\begin{array}{l}\text { The total sample of listed coal mining companies that are paying dividends for three consecutive } \\
\text { years }\end{array}$ & 8 \\
\hline
\end{tabular}

The companies that were delisted from the IDX were Bara Jaya International Tbk., Garda Tujuh Buana Tbk., Perdana Karya Perkasa Tbk., and Golden Eagle Energy Tbk. Companies that do not publish audited financial statements are Borneo Lumbung Energy \& Metal Tbk. and Alfa Energi Investama Tbk. Based on table 1, eight coal mining companies meet the predetermined criteria. The following are the names of the companies selected to be the sample in this research:

Table 2. Coal Mining Company Sample

\begin{tabular}{ccl}
\hline No. & Stock Ticker & \multicolumn{1}{c}{ Company Name } \\
\hline 1. & ADRO & Adora Energy Tbk. \\
\hline 2. & BSSR & Baramulti Suksessarana Tbk. \\
\hline 3. & GEMS & Golden Energy Mines Tbk. \\
\hline 4. & ITMG & Indo Tambangraya Megah Tbk. \\
\hline 5. & KKGI & Resource Alam Indonesia Tbk. \\
\hline 6. & MBAP & Mitrabara Adiperdana Tbk. \\
\hline 7. & MYOH & Samindo Resources Tbk. (formerly Myoh Technology Tbk.) \\
\hline 8. & PTBA & Tambang Batubara Bukit Asam (Persero) Tbk. \\
\hline
\end{tabular}




\section{Analysis Method}

This research uses panel data regression analysis, a combination of time series and cross-sectional data. The linear regression model used is as follows:

$$
\mathrm{Y}=\alpha+\beta 1 \mathrm{X}_{1}+\beta 2 \mathrm{X}_{2}+\beta 3 \mathrm{X}_{3}+\beta 4 \mathrm{X}_{4}+\beta 5 \mathrm{X}_{5}+\mathrm{e}
$$

Variables:

$\mathrm{Y}=$ Dividend payout ratio

$\alpha \quad=$ Constant

$\beta \mathrm{i} \quad=$ Regression coefficient (i)

$\mathrm{X}_{1} \quad=$ Current ratio

$\mathrm{X}_{2} \quad=$ Debt to equity ratio

$\mathrm{X}_{3} \quad=$ Return on asset

$\mathrm{X}_{4} \quad=$ Total asset turnover ratio

$\mathrm{X}_{5} \quad=$ Working capital turnover ratio

e $\quad=$ Error term

The method of estimating the regression model was carried out with three approaches, namely:

1. The Common Effect Model: Combines time-series and cross-section data using the ordinary least squares method.

2. The Fixed Effect Model: Used when the data type has a constant slope but different intercepts according to the cross-section data unit.

3. The Random Effect Model used for differences in individual characteristics and, the error of the model accommodates the time.

The panel data regression model's selection was carried out by three tests, namely the Chow test, the Hausman test, and the Lagrange Multiplier test.

Hypothesis testing in this study includes the t-test to partially test whether each independent variable influences the dependent variable and the Coefficient of Determination (Adjusted R Square or $\mathrm{R}^{2}$ ) to determine the proportion of total variance in the dependent variable explained by the independent variable.

\section{Operationalization of Research Variables}

The variables used in this research are shown in the table below.

Table 3. Operationalization of Research Variables

\begin{tabular}{lllc}
\hline Code & \multicolumn{1}{c}{ Variable } & \multicolumn{1}{c}{ Indicator } & Scale \\
\hline $\mathrm{X}_{1}$ & Current Ratio & Current Ratio $=\frac{\text { Current Assets }}{\text { Current Liabilities }}$ & Ratio \\
\hline $\mathrm{X}_{2}$ & Debt to Equity Ratio & Debt to Equity Ratio $=\frac{\text { Total Debt }}{\text { Equity }}$ & Ratio \\
\hline $\mathrm{X}_{3}$ & Return on Asset & ROA $=\frac{\text { Net Profit After Tax }}{\text { Total Assets }}$ & Ratio \\
\hline $\mathrm{X}_{4}$ & Total Asset Turnover Ratio & Total Assets Turnover $=\frac{\text { Sales }}{\text { Total Asset }}$ & Ratio \\
\hline $\mathrm{X}_{5}$ & Working Capital Turnover Ratio & WCT $=\frac{\text { Sales }}{\text { Current Asset }- \text { Current Debt }}$ & Ratio \\
\hline $\mathrm{Y}$ & Dividend Payout Ratio & DPR $=\frac{\text { Total Dividend }}{\text { Net Income }}$ & Ratio \\
\hline
\end{tabular}

Regarding the operationalization of the variables used, the data is taken from the balance sheet and income statement. 


\section{RESULT AND DISCUSSION}

The data calculations were obtained from the financial statements of coal companies for 2016-2018; the companies used in this research were selected samples and had met the specified criteria. The company's financial ratios were calculated using Microsoft Excel. Following is a table that shows the results of financial ratios calculations.

Table 4. Calculations Results of Coal Company's Financial Ratios

\begin{tabular}{|c|c|c|c|c|c|c|c|c|}
\hline No. & Code & Year & CR & DER & ROA & ТАTO & WCT & DPR \\
\hline 1 & ADRO & 2016 & 2.47 & 0.72 & 0.05 & 0.39 & 2.66 & 0.33 \\
\hline 2 & ADRO & 2017 & 2.56 & 0.67 & 0.08 & 0.48 & 2.70 & 0.47 \\
\hline 3 & ADRO & 2018 & 1.96 & 0.64 & 0.07 & 0.51 & 4.62 & 0.42 \\
\hline 4 & BSSR & 2016 & 1.11 & 0.44 & 0.15 & 1.32 & 45.88 & 2.19 \\
\hline 5 & BSSR & 2017 & 1.45 & 0.40 & 0.39 & 1.87 & 16.06 & 0.83 \\
\hline 6 & BSSR & 2018 & 1.21 & 0.63 & 0.28 & 1.81 & 27.71 & 0.14 \\
\hline 7 & GEMS & 2016 & 3.77 & 0.43 & 0.09 & 1.02 & 2.57 & 0.93 \\
\hline 8 & GEMS & 2017 & 1.68 & 1.02 & 0.20 & 1.29 & 4.51 & 1.02 \\
\hline 9 & GEMS & 2018 & 1.32 & 1.22 & 0.14 & 1.49 & 13.17 & 0.38 \\
\hline 10 & ITMG & 2016 & 2.26 & 0.33 & 0.11 & 1.13 & 4.56 & 1.52 \\
\hline 11 & ITMG & 2017 & 2.43 & 0.42 & 0.19 & 1.24 & 3.60 & 0.99 \\
\hline 12 & ITMG & 2018 & 1.97 & 0.49 & 0.18 & 1.39 & 5.33 & 0.83 \\
\hline 13 & KKGI & 2016 & 4.05 & 0.17 & 0.10 & 0.94 & 3.11 & 0.57 \\
\hline 14 & KKGI & 2017 & 3.54 & 0.19 & 0.13 & 0.80 & 2.90 & 0.05 \\
\hline 15 & KKGI & 2018 & 1.48 & 0.35 & 0.00 & 0.49 & 6.04 & 1.45 \\
\hline 16 & MBAP & 2016 & 3.45 & 0.27 & 0.23 & 1.61 & 3.44 & 1.03 \\
\hline 17 & MBAP & 2017 & 3.16 & 0.31 & 0.36 & 1.61 & 3.48 & 0.83 \\
\hline 18 & MBAP & 2018 & 2.64 & 0.40 & 0.29 & 1.49 & 3.85 & 0.28 \\
\hline 19 & MYOH & 2016 & 4.30 & 0.37 & 0.14 & 1.29 & 2.95 & 0.80 \\
\hline 20 & MYOH & 2017 & 2.85 & 0.33 & 0.09 & 1.38 & 3.37 & 1.46 \\
\hline 21 & МТOH & 2018 & 3.48 & 0.33 & 0.20 & 1.59 & 3.30 & 0.61 \\
\hline 22 & PTBA & 2016 & 1.66 & 0.76 & 0.11 & 0.76 & 4.25 & 0.30 \\
\hline 23 & PTBA & 2017 & 2.53 & 0.59 & 0.21 & 0.89 & 2.90 & 0.74 \\
\hline 24 & PTBA & 2018 & 2.38 & 0.49 & 0.21 & 0.88 & 3.11 & 0.74 \\
\hline
\end{tabular}

Source: financial statements of coal companies and have been reprocessed.

The model selection test on table 5 declared that the most appropriate model for this research is the common effect model.

Table 5. Panel Data Regression Model Selection Test Results

\begin{tabular}{lccc}
\hline \multicolumn{1}{c}{ Tests } & Statistic Value & Probability Value & Model \\
\hline Chow test & 1.601294 & 0.2329 & Common Effect \\
\hline Hausman test & 11.062327 & 0.0502 & Random Effect \\
\hline Lagrange Multiplier test & 1.371923 & 0.2415 & Common Effect \\
\hline
\end{tabular}

The following is a panel data regression using the common effect model. 
Table 6. Panel Data Regression - Common Effect Model

\begin{tabular}{|c|c|c|c|c|}
\hline \multicolumn{5}{|c|}{$\begin{array}{l}\text { Dependent Variable: DPR } \\
\text { Method: Panel Least Squares } \\
\text { Date: } 06 / 19 / 20 \text { Time: } 15: 50 \\
\text { Sample: } 20162018 \\
\text { Periods included: } 3 \\
\text { Cross-sections included: } 8 \\
\text { Total panel (balanced) observations: } 24\end{array}$} \\
\hline Variable & Coefficient & Std. Error & t-Statistic & Prob. \\
\hline $\mathrm{C}$ & 1.678893 & 0.649828 & 2.583596 & 0.0187 \\
\hline CR & -0.217029 & 0.159052 & -1.364520 & 0.1892 \\
\hline DER & -1.043694 & 0.476448 & -2.190574 & 0.0419 \\
\hline ROA & -3.270518 & 1.575058 & -2.076443 & 0.0525 \\
\hline TATO & 0.569017 & 0.367028 & 1.550337 & 0.1385 \\
\hline WCT & 0.007814 & 0.013025 & 0.599916 & 0.5560 \\
\hline Root MSE & 0.377781 & \multicolumn{2}{|l|}{ R-squared } & 0.404899 \\
\hline Mean dependent var & 0.786667 & \multicolumn{2}{|c|}{ Adjusted R-squared } & 0.239593 \\
\hline S.D. dependent var & 0.500249 & \multicolumn{2}{|c|}{ S.E. of regression } & 0.436224 \\
\hline Akaike info criterion & 1.390995 & \multicolumn{2}{|c|}{ Sum squared resid } & 3.425241 \\
\hline Schwarz criterion & 1.685509 & \multicolumn{2}{|c|}{ Log likelihood } & -10.69194 \\
\hline Hannan-Quinn criter. & 1.469130 & \multicolumn{2}{|l|}{ F-statistic } & 2.449396 \\
\hline Durbin-Watson stat & 1.938594 & \multicolumn{2}{|c|}{ Prob. (F-statistic) } & 0.073438 \\
\hline
\end{tabular}

\section{Discussion}

The level of significance used in this research is 0.05 , which means that if the independent variable has a significance of more than 0.05 , then the independent variable does not significantly impact the dependent variable. Otherwise, if the independent variable has a significance of less than 0.05 , then the independent variable has a significant impact on the dependent variable.

\section{The Impact of Current Ratio on Dividend Payout Ratio}

Based on the current ratio variable on the dividend payout ratio regression, it can be seen that the current ratio variable has a significance value of more than 0.05 , which is equal to 0.1892 . So, it can be concluded that the current ratio variable in coal mining companies does not significantly impact the dividend payout ratio variable. The insignificant impact shows that a coal mining company's liquidity level does not affect investor's dividend payments. The reason is that an increase in liquidity at a coal mining company can be affected by an increase in coal production, which causes current assets in the form of inventories to increase. In other words, the high level of liquidity in coal companies does not affect dividend payments.

The result of this research is in line with the result of research by Ekawati et.al (2015), Herawati et.al (2018), and Amelia et.al (2019), which states that the current ratio does not affect the dividend payout ratio. However, it is not in line with the research result of Yasa et.al (2016) and Astiti et.al (2017), which states that the current ratio has a significant negative effect on the dividend payout ratio. Previous research results that are inconsistent with this research used the samples of manufacturing, basic industry, property, real estate, and building construction companies. The difference in the company's type might be the cause of that inconsistency.

\section{The Impact of Debt-To-Equity Ratio on Dividend Payment Ratio}

The test result of the debt to equity ratio variable on the dividend payout ratio shows a significance value of less than 0.05 , which is equal to 0.0419 with a coefficient value of -1.043694 , it means that every $1 \%$ increase in the debt to equity ratio variable, the dividend payout ratio variable will decrease $1.043694 . \%$. It can be concluded that the debt-to-equity ratio variable in coal mining companies has a significant negative effect on the dividend payout ratio variable. The result of this research indicates that the level of debt to equity can negatively affect dividend payments. The high level of debt to equity indicates that coal mining companies rely more on debt 
financing than financing with the company's capital. The higher the debt to equity ratio of a company, the lower the dividend payout ratio of the company. It will affect dividend payments because the company will prioritize its funds for debt payments.

The result of this research is in line with the research of Yasa et.al (2016), Herawati et.al (2018), and Firdaus et.al (2019), which state that the debt to equity ratio has a significant negative effect on the dividend payout ratio. However, it is not in line with the research result of Ekawati et.al (2015) and Astiti et.al (2017), which state that the debt to equity ratio does not affect the dividend payout ratio. Previous research results are not in line with this research due to differences in the company's type.

\section{The Impact of Return on Assets on Dividend Payout Ratio}

The return on assets variable regression on the dividend payout ratio shows a significance value of 0.0525 , which is more than 0.05 . So, it can be concluded that the return on assets variable in coal mining companies does not significantly affect the dividend payout ratio variable. The insignificance shows that the level of net income generated from total assets does not affect dividend payments. The non-significance occurs because coal mining companies have large expenditures to finance the coal mining operations; the company's cash flow has been calculated, thus not affecting dividend payments.

The result of this research is in line with the research of Welas et.al (2019) and Astiti et.al (2017), which state that return on assets does not have a significant effect on the dividend payout ratio. However, the result of this research is not in line with the research of Marlim et.al (2015), which states that return on assets has a significant negative effect on the dividend payout ratio. The result of the research by Herawati et.al (2018) states that return on assets has a significant positive effect on the dividend payout ratio. This research is not in line with previous research due to differences in the types of companies used as samples. The type of company used in previous research is manufacturing and automotive company.

\section{The Impact of Total Asset Turnover on Dividend Payout Ratio}

The total asset turnover ratio regression on the dividend payout ratio shows a significance value of more than 0.05 , equal to 0.1385 . So, it can be concluded that the total asset turnover ratio variable in coal mining companies has no significant effect on the dividend payout ratio variable. The effectiveness of a coal company in managing its assets to generate sales does not affect dividend payments. This situation can occur because coal mining companies require a significant amount of funds for their business operations, namely producing coal supplies. So, coal companies have determined the allocation of funds related to corporate financing and dividend payments, which causes the level of sales not to affect the proportion of dividend payments.

The result of this research is in line with the research result of Sutanto (2019), Rahman (2017), and Aini (2016), which state that total asset turnover does not affect the dividend payout ratio. This research is not in line with the result of research by Firdaus et.al (2019) and Welas et.al (2019), which state that total asset turnover has a significant positive effect on the dividend payout ratio. Research by Marlim et.al (2015) states that total asset turnover has a significant negative effect on the dividend payout ratio. This research is not in line with previous studies due to differences in the types of companies used as samples. In previous studies that were inconsistent with this research, the types of companies used were manufacturing and chemical industry companies.

\section{The Impact of Working Capital Turnover Ratio on Dividend Payout Ratio}

The working capital turnover regression on the dividend payout ratio shows a significance value greater than 0.05 , equal to 0.55660 . So, it can be concluded that the working capital turnover variable in coal mining companies does not significantly affect the dividend payout ratio variable. The insignificance shows that coal mining companies' effectiveness in using their working capital to generate sales does not affect investors' dividend payments. This condition can happen because coal mining companies require a large number of funds. So that the company has determined the allocation of funds to finance operations and for dividend payments. 


\section{CONCLUSIONS}

Based on the results of the analysis and testing of the current ratio, debt to equity ratio, return on assets, total asset turnover ratio, and working capital turnover ratio variable to the dividend payout ratio variable, it can be shown as follows:

1. The current ratio variable, which represents the liquidity ratio, has no partial effect on the dividend payout ratio. The level of liquidity in coal mining companies is reflected in the current ratio. A high current ratio in coal companies can be caused by an increase in the production of coal raw material supplies, resulting in a high number of current assets. Thus, the increase in liquidity does not affect dividend payments because there is no increase in cash but an increase in inventory.

2. The debt to equity ratio variable, which represents the solvency ratio, has a partial effect on the dividend payout ratio. An increase in corporate financing using debt rather than using equity results in a decrease in dividend payments. This situation happens because coal companies will prioritize their allocation of funds for debt repayment before paying dividends on the consideration of the company's sustainability.

3. The return on asset variable that represents the profitability ratio, has no partial effect on the dividend payout ratio. The amount of net income generated from the company's total assets does not affect the proportion of dividend payments. This condition can occur because coal companies need ample funds to finance their operations, so they must determine the allocation of funds for operational financing and dividend payments in advance to avoid future risks. The level of return on assets does not affect dividend payments because the funds' allocation has been determined.

4. Total asset turnover ratio, which represents the activity ratio, has no partial effect on the dividend payout ratio. This condition shows that the effectiveness of coal companies in managing their assets does not affect dividend payments. Because coal companies need a significant amount of funds to finance coal production, the company must allocate funds in advance for operational financing and dividend payments. The allocation of funds resulted in the proportion of dividend payments is then unaffected by the total asset turnover ratio level.

5. The working capital turnover ratio variable, which represents the activity ratio, does not significantly affect the dividend payout ratio. This result shows that coal companies' effectiveness in managing working capital to generate sales or income does not affect dividend payments. Working capital's inability to affect dividend payments is because coal mining companies need many funds for their operations. So, it is necessary to determine the allocation of funds, both for corporate financing and dividend payments. The reasons, as mentioned earlier, have resulted in the proportion of dividend payments unaffected by the level of working capital turnover ratio.

\section{REFERENCES}

Amelia, Y., Asmara, R.Y. (2019). The Effect of Current Ratio, Debt to Equity Ratio and Return in The Consumer Goods Industry Sector Listed in Indonesia Stock Exchange 2012-2107. International Humanities and Applied Sciences Journal. Volume 2, Issue 2, May 2019.

Aini, S.N. (2016). Pengaruh Total Turnover, Current Ratio, Debt to Equity Ratio, and Return on Asset Terhadap Kebijakan Dividend Pada Perusahaan BUMN di Bursa Efek Indonesia. Skripsi. Sekolah Tinggi Ilmu Ekonomi PERBANAS.

Astiti, N.K.A., Yuniarta, G.A., Sujana, E. (2017). Pengaruh Debt to Equity, Current Ratio, Net Present Margin, Return on Asset, Terhadap Dividend Payout Ratio studi pada perusahaan Basic Industry dan Properti, Real Estate \& Building Construction yang terdaftar di Bursa Efek Indonesia Periode 2011-2015. Journal Akuntansi Universitas Pendidikan Ganesha. Volume 7 No. 1 Tahun 2017.

Batubara. (2018). Indonesia Investments. https://www.indonesia-invesments.com/id/bisnis/komoditas/batu-bara/ item 236

Bougie., \& Sekaran. (2013). Research Methods for Business: A Skill Building Approach. John Wiley \& Sons, Inc. 
Brighman, E.F., \& Houston J.F. (2019). Fundamentals of Financial Management. Cengage.

Duli, N. (2019). Metodologi Penelitian Kuantitatif: Beberapa Konsep Dasar untuk Penulisan Skripsi \& Analisis Data dengan SPSS. Deepublish Publisher.

Ekawati, G., Siswoyo, B.B. (2015). The Effects of Current Ratio and Debt to Equity Ratio on Dividend Policy Through Net Profit Margin. Research Journal of Financial and Accounting. Vol. 6 No. 24. 2015.

Firdaus, I., Handyani, P. (2019). Pengaruh DER dan NPM Terhadap Kebijakan Dividend. Journal of Applied Accounting and Finance. Volume 3, Number 1. 2019. Page 77-84.

Ghozali, I. (2018). Aplikasi Analisis Multivariate dengan Program IBM SPSS 25 (9 $9^{\text {th }}$ ed.). Badan Penerbit Universitas Diponegoro.

Gitman, L.J., \& Zutter, C.J. (2015). Principal of Managerial Finance, Fourteenth Edition (14 ${ }^{\text {th }}$ ed.). Pearson Education Limited.

Hasan, M.I. (2002). Pokok-Pokok Materi Metodologi Penelitian dan Aplikasinya. Ghalia.

Hery. (2015). Analisis Kinerja Manajemen. PT Grasindo.

Herawati, A., Fauzia, F.I. (2018). The Effect of Current Ratio, Debt to Equity Ratio and Return on Asset on Dividend Payout Ratio in Sub-sector Automotive and Component Listed in Indonesia Stock Exchange in Period 2012-2106. Knowledge, E., Social Sciences. Volume 2018.Jensen, M.C., \& Meckling, W.H. (1976). Theory of The Firm: Managerial Behavior, Agency Costs and Ownership Structure. Journal of Financial Economics, 3, 305-360.

Jumingan. (2014). Analisis Laporan Keuangan. PT. Bimi Aksara.

Kasmir. (2016). Analisis Laporan Keuangan. PT. Raja Grafindo Persada.

Kasmir (2014). Analisis Laporan Keuangan. PT. Raja Grafindo Persada.

Kasmir. (2012). Analisis Laporan Keuangan. PT. Raja Grafindo Persada.

Kostini, N., \& Marliasari, F. (2017). The Impact of Working Capital Management Toward Profitability on Food and Beverage Companies Listed in Indonesia Stock Exchange. Review of Integrative Business \& Economics, 6(2), 350-358.

Leonard, L., Irawan, D., \& Aziliya, D. (2019). Simalaka Ekspor Batu Bara: Harga Versus Devisa. Bisnis.com. ekonomi.bisnis.com/read/20190219/44/890595/simalaka-ekspor-batu-bara-harga-versus-devisa.

Maulana, Y. S. (2017). Pengaruh Perputaran Modal Kerja dan Perputaran Aktiva Tetap Terhadap Profitabilitas Pada PT Mayora Indah TBK. 1(2), 197-205.

Marlim, P., Arifin, A.Z. (2015). Analysis of Cash Position, Debt to Equity Ratio, Return on Asset, Growth Potential, and Total Assets Turn Over Effect to Dividend Pay Out Ratio on Companies Listed at Indonesia Stock Exchange 2009-2011. IJABER, Vol. 13, No. 7. 2015. Page 5403-5419.

Murhadi, W. R. (2013). Analisis Laporan Keuangan: Proyeksi dan Valuasi Saham. Salemba Empat.

Myšková, R., \& Hájek, P. (2017). Comprehensive Assessment of Firm Financial Performance Using Financial Ratios and Linguistic Analysis of Annual Reports. Journal of International Studies, 10(4), 96-108. doi. org/10.14254/2071-8330.2017/10-4/7

Osadchy, E.A., Akhmetshin, E.M., Amirova, E.F., Bochkareva, T.N., Gazizyanova, Yu.Yu., Ymashev, A.V. (2018). Financial Statements of a Company as an Information Base for Decision-Making in a Transforming Economy. European Research Studies Journal. Volume XXA, Issue 2, 2018. Pp. 339-350.

Rahman, A.F. (2017). Pengaruh Rasio Keuangan Terhadap Dividend Payout Ratio Perusahaan Manufaktur di Bursa Efek Indonesia. Skripsi. Universitas Negeri Yogyakarta.

Sutanto, S.N. (2019). Pengaruh Debt to Equity Ratio, Fixed Assets Ratio and Total Asset Turnover Ratio Terhadap Dividend Payout Ratio Pada Perusahaan Sektor Perbankan yang Terdaftar di LQ45 Bursa Efek Indonesia. Skripsi. Universitas Kristen Maranatha.

Welas., Nugroho, S.Y. (2019). Analisis Faktor-Faktor yang Mempengaruhi Kebijakan Dividen. Published by 
LPMP Imperium.

ejournal.imperiuminstitute.org/index.php/AKURASI.

Yasa, K.D., Wirawati, N.G.P. (2016). Pengaruh Net Profit Margin, Current Ratio, and Debt to Equity Ratio pada Dividend Payout Ratio. E. Journal Akuntansi Universitas Udayana. Vo. 16.2. Agustus. 2016. Page 921 950. 